\title{
The Idealization of Risk-Profit Sharing in Partnership-Based Sukuk (Islamic Bonds): 'Why' Sukuk Are Experiencing Default?
}

\author{
RAFISAH MAT RADZI \\ Senior Lecturer, Universiti Sains Malaysia \\ Email: rafisah@usm.my \\ Tel: +604 6532314
}

AMIR SHAHARUDDIN

Associate Professor, Universiti Sains Islam Malaysia

Email: amir@usim.edu.my

Tel: +606 7986301

\begin{abstract}
This paper critically evaluates the practice of partnership-based or equity-based sukuk (Islamic bonds) structure in light of the problem concerning default. The study focuses on the debt characteristics built into the equity structure before and after the Accounting and Auditing Organization for Islamic Financial Institutions (AAOIFI) announcement in 2008. A closer examination the structure of two musharakah (joint venture) sukuk that practice in the market has demonstrated 'why' sukuk are experiencing default situations. While ideally the element of risk avoidance and profit-sharing should present in the structure, due to market presssure, these structural features practically turned the equity-based profit-and-losssharing arrangements into fixed-income instruments. Ultimately, the structure that should practice 'no concept of fixed obligation' has in fact defaulted on its obligations.
\end{abstract}

Keywords: Sukuk (Islamic Bonds), Shariah (Islamic Law), Default, Profit-sharing, Musharakah (Joint venture).

\section{Introduction}

The global financial crisis of 2008 witnessed a number of defaults and near defaults of sukuk, demonstrating that it has not been spared the risks that conventional bonds face. Since conventional bonds are a pure debt obligation, the chance that the corporate issuer will default on its debt obligations is severe, and is a major consequence of the crisis. However, the default of musharakah (joint venture) and mudharabah (profit-sharing between entrepreneur and investors) sukuk has generated serious and numerous questions about the underlying structures. In this partnership contract, the interests of the two parties move in harmony both during the upside as well as during the downside of the business. The partners share in profit according to a pre-agreed ratio. If a loss occurs it will be shared pro-rata in proportion to the capital share of the partners. These key principles raise some doubts about the possibility of default given that sukuk are structured as bona fide risk-sharing arrangements. Therefore, this paper aims to evaluate the practice of partnership-based or equity-based sukuk in light of the default, by examining two defaults of musharakah sukuk before and after the Accounting and Auditing Organization for Islamic Financial Institutions (AAOIFI) announcement in 2008. Since in reality much of the partnership-based sukuk structure today is focused on replicating how conventional bonds work, there should be no surprise when a default occurs on its obligation. 
The following sections will, in order, present an overview of sukuk default and type of sukuk. It is then followed by the discussion of idealization of profit-loss sharing in musharakah and mudharabah sukuk and its argument against default. Further, two musharakah sukuk default scenarios were examined by providing the AAOIFI resolution that was issued in 2008. Finally, conventional mind-set risk-averse investors for the sukuk market are discussed.

\section{Sukuk Default: Debt-Type and Equity-Type}

The Islamic banking and finance sector is increasing its market share in the global finance industry, especially since the first appearance of sukuk in the 1970s. Sukuk are the fastest growing facet of the Islamic capital market and carry with them a sense of reliability and hope for the future. They are instrument that complies with Shariah, Islamic religious law. Even though the sukuk market has been growing at an average of more than $25 \%$ per year (IRTI, 2013), it has not been spared the risks that conventional bonds have faced. The 2008 global financial crisis witnessed a number of defaults and near defaults of sukuk. For example, the East Cameroon sukuk issued by East Cameroon Partners LP is considered to be the first sukuk that ran into trouble in 2008, followed by a series of sukuk defaults such as: Gulf Holding Company (Villamar Sukūk) (Bahrain), Dana Gas (United Arab Emirates or UAE), Gulf Finance House (Bahrain), Tabreed Sukūk (UAE), International Investment Corporation (Kuwait), Saad Group (Golden Belt) (Saudi Arabia), Arcapita Bank (Bahrain), The Investment Dar (Kuwait), and the close sukuk default by The Nakheel Group (UAE). The totals of these sukuk defaults amounted to US\$3.166 billion which accounted for about $7 \%$ of the total sukuk issuance in 2008 (Ali, 2016). Then as the year 2009 ended the global sukuk market was rocked by at least 15 cases that rose to 31 defaults by early 2012 . The most worrying aspect of this is that there have been 36 cases of corporate sukuk defaults by 33 issuers from 1990 to 2012, with the defaulted value amounting to RM 6.848 billion in Malaysia's market alone (Khnifer, 2011). It seems that sukuk defaults represent a new phenomenon in the GCC (Gulf Cooperation Council) market and Malaysia.

The most obvious difference between conventional finance and Islamic finance is that Islamic finance prohibits the charging of interest so that it is consistent with Islamic teachings. In conventional finance, those who default on their payments or that consistently pay late are usually penalized by having their interest rates altered, usually connected to their credit rating. Following Moody's (2011), default is defined as the failure to make scheduled principal or interest payments and the defaults can be grouped into three types of credit events: (i) a missed or delayed disbursement; (ii) bankruptcy or legal blocks of interest and/or principal; and (iii) a distressed exchange occurs to the issuers amounting to a diminished financial obligation or helping the borrower avoid default. In general, the agencies' rating factors vary in downgrading (or lowering) bond rating; however, one of the most important is the risk of default, which is the issuer's failure to make scheduled interest and principal payments. Since conventional bonds constitute a pure debt obligation, the rating addresses the possibility that a financial obligation will not be honored as promised.

Even though sukuk are much popular as 'Islamic bonds' or 'Shariah-compliant bonds', it is very important to note that sukuk are not always debt instruments. Sometimes they are a form of equity depending on how they are structured. In fact, AAOIFI's Financial Accounting Standard No. 25 does make a distinction between debt-type sukuk and equity-type sukuk. Debt-type instruments are defined as "investments that have terms that provide fixed or determinable payments of profit and capital" that may be characterized in the ijarah (lease), istisna' (contract of exchange with deferred delivery) and salam (advance purchase) sukuk. Equity-type instruments are defined as "investments that do not exhibit features of debt-type instruments and include instruments that evidence a residual interest in the assets of an entity after deducting all its liabilities." This partnership sukuk such as musharakah and mudharabah, via share ownership, is very similar to common share securities with claims to profits only if profits are earned after sharing in the risk of the project being funded. 
In practice, income and capital guarantee is incorporated into the sukuk structure (Abdullah, 2012). The income guarantees require issuers to pay investors a specified amount of "dividends" on specific dates. The dividends are calculated as a percentage of the total amount "invested" rather than as a percentage of total profits (similar to the way interest payments are determined as a percentage of the total amount of a given loan). Meanwhile, the capital guarantee requires originators to refund to investors their capital in full, on a specific day in the future, known as the maturity date. To comply with Shariah law - at least in a formal sense - the refund was accomplished by requiring originators to repurchase the underlying assets from investors on an agreed-upon date. The price at which the assets were repurchased was identical to the price at which they were first sold to investors. This had the effect of returning to "investors" exactly the same amount they "invested" when they initially purchased the assets. This structure portrays a contractual debt obligation, even though the debt originates from a sale or lease transaction, unlike a debt in a bond which comes from a loan contract. Therefore, as far as credit rating is concerned with reference to default of debt obligation, the long-term debt-based sukuk tend to default rather than the profit-sharing sukuk (Majid, Shahimi, \& Abdullah, 2011). Since debt-type sukuk behave like corporate bonds in terms of capital preservation, periodic distribution frequency and rate of return, such a default is nothing to ponder. However, when defaults did happen for musharakah sukuk, in particular Villamar, Kuwaiti's Investment Dar and East Cameroon Gas Company, such events tested the validity of the concept of profit-sharing that underpin partnership-based sukuk. Considering the idealization of profit-loss sharing that underpins the structure in musharakah and mudharabah sukuk, a number of scholars have raised questions about such default and this has triggered further discussion.

The concept and idealization of profit-loss sharing in musharakah and mudharabah sukuk and its argument against default

Sukuk must comply with Islamic law principles, which have the overarching objective of social justice at their core. In financial transactions, those principles may be summarized by the prohibitions of (1) illicit gain (riba), (2) excessive risk taking (gharar), (3) speculation (maysir), (4) sale of assets one does not own, and (5) funding matters prohibited by Islamic law (e.g. pork products) as well as the requirements that (1) risks and profits be shared and (2) transactions be based on real assets. As a result of the prohibitions on financial transactions, conventional loans are not permitted within Islam (Iqbal \& Mirakhor, 2007). Hence, Islamic finance contains different financing techniques to fulfil the needs of Islamic entrepreneurs who require financing. Therefore, sukuk can be structured in various form based on acceptable types of contract in Islamic law such as salam, istisna', musharakah, mudharabah and ijarah. Different structures serve different commercial purposes and are suited to different circumstances. However, within Islamic law the real and ideal instruments of financing are the profit-and-loss-sharing agreements, such as musharakah and mudharabah agreements. These forms of equity-based financing are in line with the Islamic view on financial transactions that one cannot be entitled to a reward if one has not taken any risk (Salah, 2011).

Musharakah and mudharabah are both contracts which serve to initiate a joint venture whereby all the partners participate in the business right from its inception. They continue to be partners up to the end of the business when all the assets are liquidated (Usmani, 2002). Musharakah means relationship established under a contract by the mutual consent of the parties for sharing profits and losses, arising from a joint enterprise or venture. All the partners contribute capital under a musharakah arrangement, while the management of the partnership may be assigned to a particular partner or third party (Usmani, 1999a). Meanwhile, a mudharabah is an investment partnership, whereby the investor ( $\mathrm{rabb}$ al-mal) provides capital to another party/entrepreneur (mudharib) in order to undertake a business/investment activity. While profits are shared on a pre-agreed ratio, loss of investment is born by the investor only (Usmani, 2002). In this context, the primary difference between these two types of commercial arrangements is whether the partner in the contract: firstly, provides the capital contribution; and secondly, participates in the management of the partnership or only one of these functions. 
Since musharakah and mudharabah are premised on profit-risk sharing, one of the most important elements of the contract is the distribution of profit. In the musharakah contract, the proportion of profit to be distributed between partners must be agreed upon at the time of the contract's inception (Usmani, 1999b). If there is no mention of the proportion of profit then the contract is not valid according to the Shariah perspective. This is because the ratio of profit for each partner must be in proportion to the actual profit accrued to the business and not in proportion to the capital invested by him. Also, it is not allowed to fix a lump sum amount for any one of the contracting parties, or any rate of profit tied up with his investment ${ }^{1}$. According to Shariah, the correct basis for the distribution of profit would be an agreed percentage of the actual profit accrued to the business. Similarly, at the inception of the mudharabah contract, contracting parties should agree on a definite proportion of the actual profit to which each of them is entitled. No particular proportion has been prescribed by Shariah, rather, it has been left to their mutual consent. They can share the profit in equal proportions and they can allocate different proportions for the rab-al-maal and the mudharib. However, they cannot allocate a lump sum amount of profit for any party, nor can they determine the share of any party at a specific rate tied up with the capital. What can be agreed upon, however, according to Shariah law is the profit-sharing ratio.

Given that musharakah and mudharabah sukuk are designed as profit-risk sharing securities, the profits by definition depend on the efficiency assets generating them (Abdullah, 2011). This means that periodic payments depend on the performance of the underlying assets or projects, since those projects' revenues are the sole source of the periodic payments made to the sukuk holders. On this issue, sukuk holders do not receive a fixed return and there is even a risk that the sukuk holders will not receive the expected return in case the underlying projects do not succeed. In terms of risks, it must be shared among the originator and investors, with the likelihood of fluctuations in dividend/profit payment and capital redemption (Saeed \& Salah, 2012). Premised on this structure, the ideal of this sukuk exhibits the interest of the two parties being in harmony during the upside as well as downside of the business in a partnership contract.

Considering the structure that departs from a typical debt-based arrangement, the default of partnership sukuk is inconsistent with the definition of default given by credit rating agencies. As noted earlier, default means breaching some obligation of payment i.e. interest installment during the period of the contract or the debt principal amount at the end. Here, some Islamic scholars argue 'why' these sukuk fail to deliver their promises. According to Kidwai (2009) as per Shariah law, there is no concept of fixed obligation; it is only 'profit' that matters. Looking from the investors' perspective, they need some certainty on the return - be they Islamic or conventional. This quagmire between the Shariah law and investors is further accentuated by the financial crisis as more of these Islamic instruments face stresses similar to those faced by their conventional counterparts, raising questions on their value proposition over the conventional form of finance. Abdullah (2011) and Zaher and Wijnbergen (2013) raise some doubt on the possibility of default arising given that sukuk are structured as bona fide risk-sharing enterprises. There may be losses but there are no defaults. 'If Shariah are to be adhered to, the originator to', the originator or obligor need not pay sukuk holders when they are 'no profits to be distributed. Abdullah (2011) further argues that since all business carries risk, there can never be a guarantee of profits any more than there can be a guarantee against losses. Bona fide risk-sharing instruments do not come with predetermined and 'guaranteed' profits, 'maturity profits' or 'refunds' of shareholders' capital. In a recent study, Ali (2016) argues that reasonably, there can never be default but a bankruptcy or insolvency is possible if the business is not continued due to low levels of profit. In a musharakah, the partners share in profits and losses, so there is no contractually defined fixed payment; neither can their principal amount be guaranteed at maturity. The winding up is a matter of selling the assets and distributing the proceeds among the partners pro rata to their respective share capital in the business. Following this, the concept of risk-profit sharing underpinning the partnership

${ }^{1}$ Suppose A and B enter into a partnership and agree between them that A shall be given RS20,000 per month as his share in the profit, and the remaining profit will go to B, this kind of partnership will be rejected by Shariah. Similarly, if they agree that A will get $20 \%$ of his investment, the contract will be pronounced as invalid by Shariah. 
and Shariah scholars' arguments have prompted further investigation into defaulted partnership based on the sukuk structure itself.

\section{Musharakah sukuk default: case study of the Investment Dar}

The Investment Dar Company (TID), a Kuwaiti company that owns half of the car manufacturer, Aston Martin, was established in 1994 with KD22.80 million (US\$83.3 million). The company is currently one of the largest finance and real estate companies in Kuwait as well as in the GCC. In 2008, the global economic crisis put a lot of pressure on the global economy, and seriously undermined the Kuwait market as well. The Kuwaiti-based company Investment Dar experienced such financial distress and it became the first Kuwaiti sukuk issue to default (Trad \& Bhuyan, 2015). The Dar Investment Company not only defaulted on its first sukuk issue worth US\$100 million issued in 2005 with the collaboration of ABC Islamic Bank (Bahrain); it also defaulted on its second US\$150 million musharakah Sukuk with a 5-year term, which was issued in 2006. The first sukuk default occurred on May 12, 2009, when Investment Dar (TID), failed to make the periodic payments on a US\$100 million sukuk.

Shortly after the default on the first sukuk, Investment Dar confirmed that it was not in a position to settle a periodic distribution amounting to US\$3.3 million which was due on April 12, 2010 for the second sukuk (Parker, 2010). Following these defaults, the company entered into a restructuring process and demanded a halt on all its debt for a temporary period because it could not service its debt of around US $\$ 3.5$ billion. Investment Dar obtained court protection under Kuwait's new financial stability law, which halted all insolvency-related lawsuits against the company. Investment Dar thereafter agreed with sukuk holders to restructure the debt over a six-year period (Friel \& Kumpf, 2015).

Regarding the second case of sukuk issuance, The Investment Dar Global Sukuk I Limited acted as a Special Purpose Vehicle (SPV), which was established in the Cayman Islands. An offering circular of The Investment Dar sukuk structure demonstrated that profits would be distributed among the partners (SPV and Investment Dar Company) in proportion to their respective capital contribution. The musharakah assets were converted into 150 units, in which Investment Dar acquired 76.83 units and the issuer held 73.17 units. A Musharakah agreement states that: 'Each partner shall be entitled to share in the profits of musharakah, and bear losses in respect of the musharakah' proportional to their investment in total musharakah assets. Returns on the underlying assets were to be shared between the partners. This would imply that the periodic payments to the sukuk holders were not fixed. However, the issuer would make a payment of periodically distributed profits to sukuk holders that were equal to LIBOR plus $1.25 \%$ for the first 3 year and LIBOR, plus $1.75 \%$ for the remaining years, distributed semi-annually. This payment would imply the practice as employed for conventional bonds, since the sukuk arrangement offered a return that was a fixed percentage, usually based on LIBOR (see Box 1). The prescribed percentages denoted that the sukuk were not linked to the expected profits from the enterprise, but to the cost of financing or to the prevalent rates of interest in the market and pre-agreed in the contract. While it can be argued that the use of LIBOR is for the benchmark interest rates- the fact is that the sukuk-holders were getting fixed returns. This arrangement is contrary to Shariah injunctions as the musharakah contract always offers a return subject to the actual performance of the musharakah proportional to the investors' shareholding (ElHawary, Grais, \& Iqbal, 2004).

In the meantime, the sukuk structure also provides a return for management services, this being an initial fee of US\$100 and incentive fees in respect of any accounting period. The musharakah accounts show a net cash profit payable to the issuer greater than the periodic distribution profit amount (LIBOR plus 'margin'). The mechanism also used for the fixed return is that of the 'incentive fee', i.e. in the scenario where returns are greater than a certain hurdle of promised return, all the upside is given to the management party as an 'incentive fee'. On the other hand, if the profits are less than what was anticipated, the issuer/obligor stands ready with a liquidity facility to make up the shortfall (Kapetanovic \& Becic, 2009). 
Box 1: The Investment Dar (TID) sukuk structure

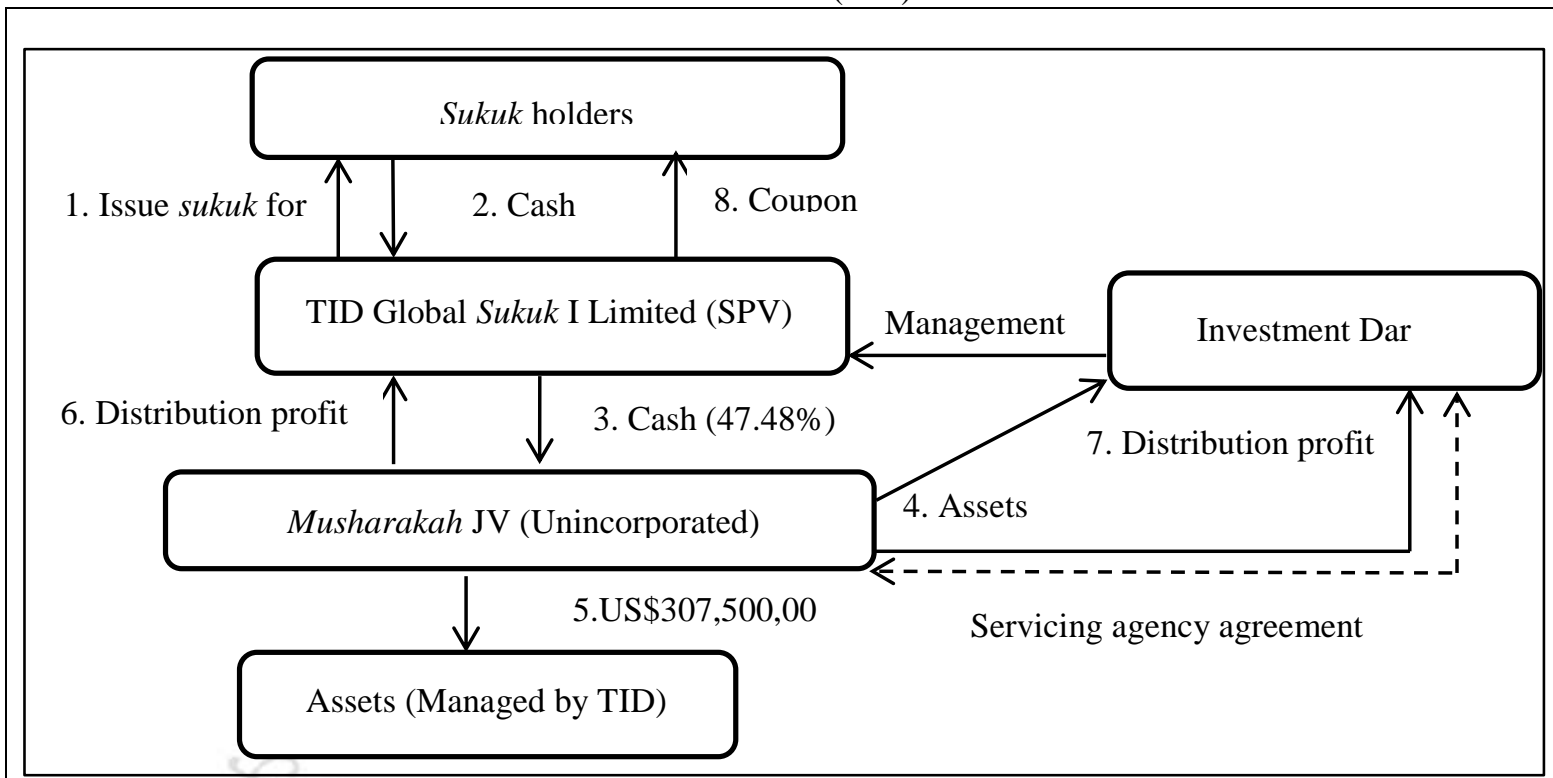

In 2005, TID issued the first musharakah sukuk with the collaboration of ABC Islamic Bank (Bahrain), by offering return 6-month LIBOR plus 2\% annual profit. TID achieved another success when its sukuk of U\$150 million was issued in 2006. The sukuk structure was also structured as musharakah, with a tenure lasting 5 years and 6 months (due 2011). This sukuk issue promised LIBOR plus $1.25 \%$ for the first 3 years and LIBOR plus $1.75 \%$ for the remaining years, distributed semi-annually. Some details on the transaction are summarized here:

1. The SPV Company issues the musharakah sukuk from the sukuk holders of US\$150,000,000 Trust Certificates Musharakah Sukuk.

2. Sukuk holders will proceed with cash US $\$ 150,000,000$ to the issuer.

3. The SPV Company will contribute $48.78 \%$ of the capital in cash to the musharakah Joint Venture for the purpose of purchasing specific assets on the basis of Sharikat al-Melk.

4. Investment Dar will contribute $51.22 \%$ of the capital in-kind in the form of vehicles and real estate, on the basis of Sharikat al-Melk which will be valued at their actual value.

5. The total amount of capital - US\$307,500,000 of the underlying assets - will be invested in accordance with purchasing specific assets, i.e. motor vehicles and property assets.

6 to 7 Profits will be distributed among the partners (SPV and Investment Dar Company) in proportion to their respective capital contribution.

8. SPV pays the coupon payment to the sukuk holders.

In consideration for acting as the management agent, the Issuer and TID shall pay the Management Agent an initial fee of US $\$ 100$ (payable on the Closing Date) and Incentive Fees in respect of any Accounting Period, the Musharakah Accounts show a Net Cash Profit payable to the Issuer greater than the Periodic Distribution Profit Amount. The originator also provides the purchase undertaking,

a) An 'Exercise Notice' by the issuer to purchase the issuer's units at 'Dissolution Distribution Amount' which was equivalent to the face value of sukuk plus any unpaid periodic distribution amount.

b) Redemption notice to purchase the issuer's units at 'Early Redemption Amount', also equivalent to the face value of sukuk plus any unpaid periodic distribution amount.

c) Occurrence of Dissolution Event, to purchase the issuer's units at 'Dissolution Distribution Amount'

Sources: The Investment Dar's website and Zaheer and Wijnbergen (2013) 
Some justify this practice by agreeing that any profits in excess of the pre-agreed LIBOR-related percentage payment to investors will be paid to the manager of the company as an incentive payment. This again mimics conventional finance and undermines the risk-sharing principle in Islamic finance. The violation of Islamic law in this case is thus two-fold. Firstly, the risks are not borne to a greater extent by investors (since their periodic returns are fixed, or related to benchmark interest rates), and secondly, excess profits which should be paid out to investors (since they have to take more risk) are actually paid out to managers as incentive fees (Ariff, Safari, \& Mohamad, 2012). Although Usmani (2007, p.5-6) extensively explains from a Shariah perspective that incentive fees could be permissible, in the case of sukuk they are forbidden since they are based on interest rates. They limit the profit-loss sharing arrangement between investors and managers and consequently defeats the purpose of this mode of Islamic finance.

As an additional security for the investment, the originator provided an undertaking to repurchase the SPV share in the underlying assets at the end of the sukuk period or upon any earlier insolvency event at nominal value or par value, not at market value. These mechanisms indicate guaranteeing the repayment of the principal to sukuk holders as done with conventional bonds. It is a well-established rule under Shariah that the return of investors' capital cannot be guaranteed as reward always follows the risk (Usmani, 2007; Yean, 2009). No matter how the venture goes, profitable or not, the return of investors' capital cannot be assured, and as such sukuk holders in musharakah and mudharabah must bear some risk in connection with investment based on these structures. Therefore, the purchase undertaking ${ }^{2}$ should not be based on an exercise price which is calculated by reference to the face value of sukuk. Instead, any such purchase undertaking should be predicated on partnership-based sukuk, which in turn should be based on the net asset value, market value, cash equivalent value or any price agreed upon at the time of purchase.

In summary, musharakah issued by The Investment Dar Global Sukuk I Limited demonstrated that the periodically distributed payments to the sukuk holders were fixed amounts. Any surplus over the periodic payments to the sukuk holders was for the originator as an incentive fee, annulling the possibility to pay the real (excess) profits of the musharakah to the sukuk holders as would be expected from equity-linked securities. The purchase undertaking guaranteed the principal amount of the sukuk holders, regardless of the possible appreciation or deprecation of the assets. All these features ensured that the sukuk resembled conventional bonds. In principle, a musharakah sukuk cannot be defaulted as the sukuk holder shares profit and loss with the originator. As noted earlier, the ideal of the partnership-based sukuk is that the interests of the two parties are harmonious during the 'up' and 'down' periods of the business in a partnership contract. However, given that the originator promised a fixed return in as in the case of Investment Dar sukuk contrary to musharakah principles, it can default on its obligations. While the reasons for sukuk default do vary and are mostly driven by market risk (Remo-Listana, 2010), and economic difficulties occurring in Middle East countries (Radzi \& Muhamed, 2012) shortfalls in oil and gas (Zaheer \& Wijnbergen, 2013), sukuk structures resulting from contractual covenants imported from conventional bonds have to a certain extent exacerbated the number of sukuk defaults.

Before the AAOIFI's resolution was announced in February 2008, the above described Musharakah sukuk structure (TID global sukuk I) was commonly practiced in the international Islamic finance market (see Usmani 2007). As analysed by Salah (2011), specifically the sukuk mudharabah certificates issued by DP World Sukuk Limited, IIG Funding Limited, Aabar Sukuk Limited and Dubai Sukuk Centre Limited, one can notice certain recurring features in most of the equity structures. The structure of partnership sukuk tends to encourage the 'price fixing' element which guarantees the principal and profit to sukuk holders, which has been criticized by the Chairman of the AAOIFI, Muhammad Taqi Usmani. For this reason it has prompted the AAOIFI Shariah board to develop some guidelines.

\footnotetext{
${ }^{2}$ Purchase Undertaking (PU) is a promise between issuers and investors to buy back the ownership of the sukuk at the maturity period.
} 


\section{AAOIFI Resolution issued in February 2008 on sukuk structure}

A prominent Shariah scholar, Muhammad Taqi Usmani, criticized developments in the sukuk market at the end of 2007 by proclaiming that $85 \%$ of sukuk issuances were not in line with the teachings of Shariah. The main target of his criticism was the equity-based sukuk structures - the sukuk issues based on musharakah, mudharabah, and wakalah (investment agency). His criticism mainly concerned three elements in the contemporary application of equity-based sukuk structures. First, the payment of any surplus as an incentive fee to the originating partner in the transaction is a mechanism that derives from conventional financing transactions and does not adhere to the Islamic finance concept, where the investor is taking more risks and, thus, must be rewarded for those risks taken. The payment of any surplus to the originating partner is a form of fixing the return to the investors and limits profit-and-loss-sharing between them. Second, he criticized the payment of interest-free loans. This mechanism is basically a form of fixing the periodic returns to the investors and, thus, the investors are not taking the risk that entitles them to a reward. Third, through these purchase undertakings, the originating party guaranteed the principal amount to the sukuk holders and this is not in line with the concept of profit-and-loss sharing.

The whole essence of equity-based transactions within Islamic finance is that it leads to equitable profit distribution, because the financer does not transfer all the risks to the borrower. In the meantime the borrower does not only acquire all the benefits of the investment of the financer, but the profits are rather shared between them. Responding to the critical views aired by Usmani, the Shariah board of AAOIFI issued its resolution in February 2008 to highlight the various areas in sukuk found to not be Shariahcompliant. These are summarized as follows:

1. Sukuk holders must own all the rights and obligations of the assets (tangible, usufructs or services), and these assets are to be transferred from the issuer to the sukuk holders' books;

2. In order to be tradable, sukuk cannot represent receivables or debt except for trading/financial entity sales that unintentionally convey incidental debt;

3. Sukuk managers may not cover loan shortfalls to sukuk holders, but reserve accounts established for such a purpose are permissible if disclosed in the prospectus;

4. The purchase of assets at maturity is permissible at the market value rather than the nominal/face value, although sukuk issuers/managers can guarantee capital in the event of negligence;

5. Lessees in ijarah sukuk may purchase the leased asset for its nominal value, provided the lessee is not a general partner, mudharib (working partner) or wakil (investment agent). AAOIFI standards permit the redemption of sukuk for usufructs at fair market values or at a price agreed between the parties at the time of redemption;

6. Shariah boards will review all relevant contracts/documentation related to the transaction to ensure comprehensive compliance with Shariah and oversee that implementation and operation are in accordance with Shariah.

Of these six rulings, two are relevant for the partnership-based sukuk. It would appear that the general spirit of the February 2008 AAOIFI guidelines is to shift the focus of the sukuk market away from a purely debtbased model toward an equity-based one. As such, there is a significant change in equity-based sukuk structure in the post-2008 AAOIFI resolution. The Villamar musharakah sukuk (Gulf Holding Company) was issued in May 2008, without a purchase undertaking. Similarly, for Purple Island (Bin Ladin) in 2008 no purchase undertaking featured in this mudharabah sukuk; instead a guarantee was given by the Saudi Bin Ladin Group. While Sorouh mudharabah sukuk issued in May 2008 has embedded a conditional purchase undertaking on returns principal and profit, Projek Lintasan Shah Alam (PLSA) in 2008 was issued with a purchase undertaking at market value. Nevertheless, the Villamar musharakah sukuk ran into difficulties within two years of its issuance and default resulted, triggering a number of doubts concerning the structure's legitimacy. To what extent did the sukuk comply with the AAOIFI's revised sukuk standard? Is the ideal of profit-sharing built into the structure really genuine? Or, to what extent has the guarantee of principal and profit really shifted from equity-based sukuk? 


\section{Musharakah sukuk default: case study of Villamar Ṣukūk}

In 2008, US\$190 million musharakah sukuk were issued by Villamar Sukuk Company Limited to finance the development of 'Villamar@theHarbour', a luxury residential development located within the prestigious Bahrain Financial Harbour District of Manama. The Villamar project was part of the Bahrain Financial Harbour development, promoted by the Bahrain- and Kuwait-listed Gulf Finance House. Unfortunately, this real estate development project ran into problems in the aftermath of the global financial crisis, the result being that property prices in Bahrain were under pressure. The company's 2009 income consisted largely of a 5.1 million Bahraini Dinar ( $\$ 13.5$ million) fair value gain on investment property, while no income from the sale of property units appeared in the annual report. Tenants became increasingly unwilling to take on the capital cost of fitting out new premises, making off-the-plan sales more challenging (Reuters, 2010). The company's request to delist the $\$ 190$ million sukuk was prompted by a lack of trading activity in the market in April 2010. This backdrop caused concerns among investors about the project's actual cash position (Trade Arabia, 2010). The project's cash constraints and liquidity crunch were real and the consequence was sukuk default. Court cases were filed, negotiations took place and the controversy continued with no resolution being found (Syed Ali, 2017)

Specifically, the Villamar sukuk involved The Villamar Sukuk Company Limited as the issuer and Residential South Real Estate Development (a single-person vehicle) as originator to develop and construct the project in Manama, Bahrain. The issuer, as trustee and representative of sukuk holders, would then distribute its shares and profits to the sukuk holders. Regarding the losses, these would be distributed between the issuer and originator according to their respective contributions to the project's capital. The issuer's portion of the losses was subsequently passed on to the sukuk holder. The business model of the construction project was such that in addition to the sukuk process, it relied on off-the-plan sales of residential units to generate funds for the construction and completion of the project (see Box 2).

This Villamar musharakah sukuk was launched after the issuance of the 2007 AAOIFI revised Shariah standard for sukuk. The most important characteristics of this deal were specially structured to circumvent the controversy that has engulfed Islamic finance, particularly on the equity-based sukuk wherein the capital of a partner is guaranteed by a buy-back promise by the other parties. It was an innovative sukuk securitization and the first non-recourse asset-backed estate deal for the Islamic market involving detailed financial engineering and incorporating non-recourse financing within a sukuk framework (Khan, 2010). Non-recourse means lenders can take the property pledged as collateral to satisfy debt, but they have no recourse to other assets of the issuer or sponsor. Sales made with recourse allow the buyer to resell a portion of the assets back to the seller, and thus, from an accounting perspective, are treated as financing and not a true sale (Al-Amine, 2011).

There are two opposing views amongst contemporary Shariah scholars with regards to 'guarantee' elements built in the Villamar sukuk. Following the IIFM (2009, pp.40-41), the new musharakah structure differs at least in two major ways from the older one that remained in vogue until February 2008. Firstly, the prospectus does not specify a purchase price for the co-owned assets at the time of redemption or dissolution. Secondly, the structure links periodic profit payments to whether or not the project is profitable and does not provide for the obligor to resort to Shariah-compliant funding to make up for a shortfall in any year, although the structure does include creation of a reserve account to which profits from surplus years are directed and which can be used to cover up shortfalls in following years. The prospectus includes a clear statement to this effect wherever periodic distributions are mentioned: "Certificate holders should note that the ability of the Issuer to pay any amounts (including Periodic Distribution Amounts) under the Sukuk Certificates will ultimately be dependent on the success of the Project." The sukuk does use an innovative 'security package' for the comfort of investors although they can also make use of a standby letter of credit from an Islamic bank that - among other things - comes into effect if the obligor fails to meet its obligation regarding a profit payment or redemption amount. It would be interesting to see how much interest the sukuk generated among the non-Islamic investors. 
Box 2: The Villamar sukuk structure

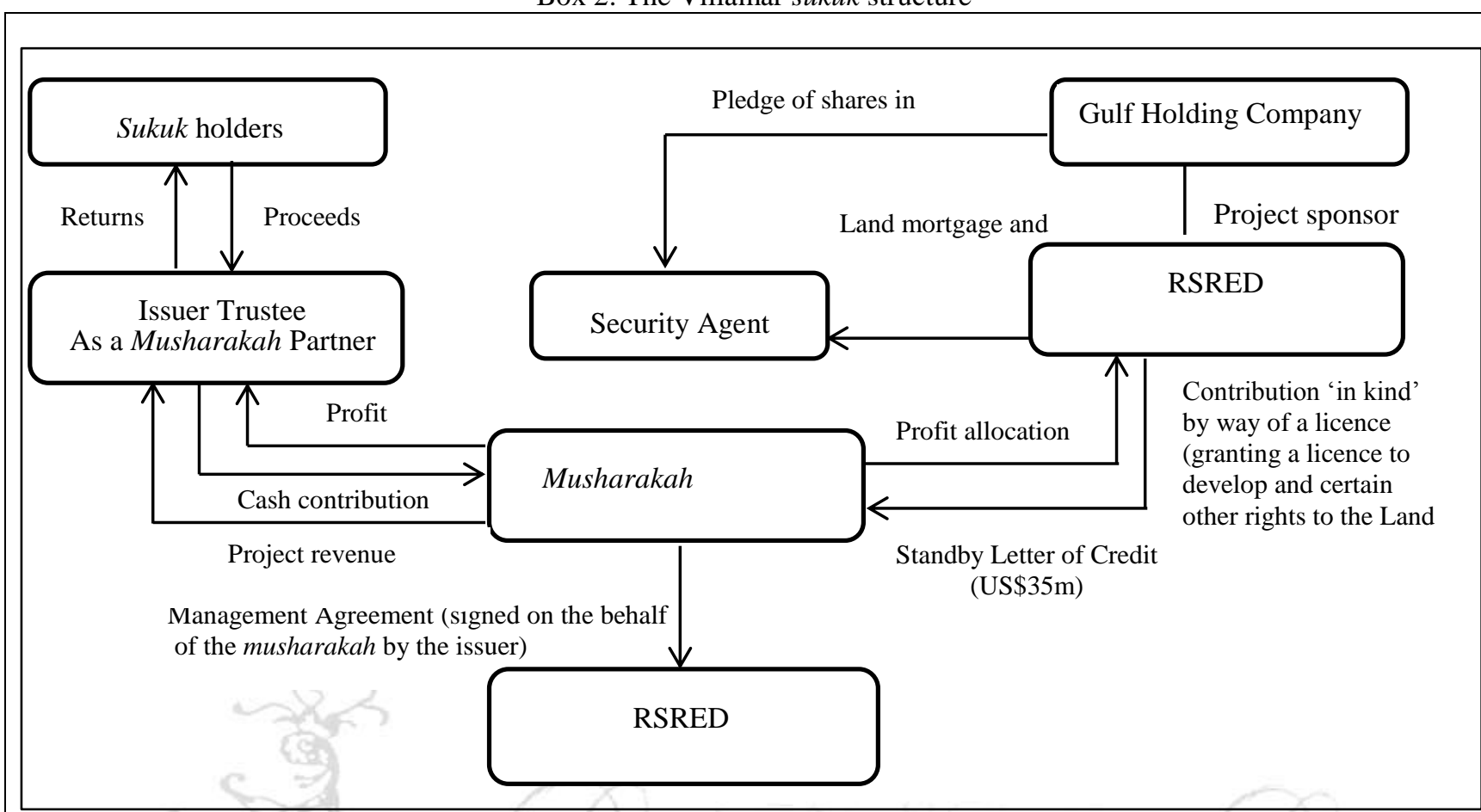

The Villamar sukuk, a 5-year maturity offered in 2008, set out to mobilize US\$190 million in 2013 to develop and construct the 'Villamar@theHarbour' which involved twisting towers, floating and terraced villas and terraced podiums. The structure is based on a musharakah agreement between the issuer (The Villamar Sukuk Company Limited) and the originator, (Residential South Real Estate Project Company (RSRED)), a 100\% subsidiary of Gulf Holding Company. The agreement was to develop three multi-storey building complexes and sell the residential units to third parties. The project was marketed separately through the approved agents - Gulf Management and Services. The issuer will contribute the total amount subscribed for by certificate holders in the sukuk offering into the musharakah which would be the “Issuer's Contribution' by way of a single cash deposit of US\$190 million into the Musharakah Disbursement Account. RSRED itself in its capacity as a musharakah partner would make its contribution 'in kind' into the musharakah by way of: (a) granting a license to develop the land and having a valuation agreed between the musharakah partners of US $\$ 100$ million; and (b) a standby letter of credit for US\$35 million. Ownership shares of these contributions were 58.46\% and $41.54 \%$ distributed by the issuer and RSRED, respectively.

The Issuer (in its capacity as Trustee) will act as a cash manager responsible for the transaction accounts and profit distributions to the musharakah partners. Meanwhile the RSRED served as the managing partner, responsible for certain services to the musharakah, including procuring the completion and delivery of the project. Sukuk holders would receive, from the proceeds and in respect of the Trust Assets, a quarterly periodic distribution equal to LIBOR plus $2.75 \%$ per annum. The margin calculated on the outstanding aggregate principal amounted of the Sukuk Certificates. The ability of the Issuer to pay any amounts (including Periodic Distribution Amounts) under the sukuk Certificates ultimately depended on the success of the project. The cash flows generated from the project (through sales, leasing, timeshare or other arrangements) shall be used for the purposes of making payments under the Sukuk Certificates on a pro rata basis on ten (10) as additional distribution amounts after the project's completion, Additional Payment Date:

(A) 7 February 2011; and

(B) each Periodic Distribution Date thereafter until (and including) 7 May 2013 (being the "Scheduled Dissolution Date"), in an amount (the "Additional Distribution Amount") equal to nineteen million Dollars (US\$19,000,000).

Source: Offering Circular Villamar Sukuk Company Limited US\$190million Trust Certificates (Sukuk AlMusharakah) 
However, the analysis undertaken by Alsayyed (2011) and Syed Ali (2017) evidenced that at least several legal elements had been built into the structure, yet ultimately they failed to structure a genuine profitsharing arrangement in the musharakah contract. First, the issuer's reward was equal to the LIBOR plus a margin together multiplied by his contributed capital amount multiplied by the number of days it was invested out of 360 days of the year. Any extra amount of profit over and above this was allocated as the share of the RSRED as an incentive payment. This is, itself, a very unlikely reward profile for a partner who would expose his capital to business risk. Second, a security package (mortgage and a standing letter of credit) was utilized to support the payment stated LIBOR plus margin and the principal amount to the sukuk holders. This is similar to the provision of a financial guarantee by one party to the other partner in which such an arrangement contravenes the spirit of profit-risk sharing. Third, albeit no purchase undertaking was evident in the structure, there was a redemption of the principal called an 'additional amount' of $10 \%$ of the principal amount (US\$190 million) on each periodically distributed amount. These imply the structure provides a contractually defined fixed capital guarantee to refund the investors' capital - which is a form of guarantee of the principal amount.

In sum, although the Villamar musharakah sukuk was launched following the revised AAOIFI resolution in 2007, the fixed income instruments with capital preservation features still existed in the structure, thus limiting the securities' equity character. As such, by incorporating the debt-like structure, the sukuk will not only mimic the profits to the holders, unavoidably they will also replicate a risk that arises in relation to all debt instruments, including the risk of default. Since this musharakah sukuk has compromised the concept of profit-sharing, it can also be defaulted on its obligations due to the financial crisis and the economic downturn that followed.

\section{Equity trapped in a debt-based market and market pressures}

Clearly, equity-grown sukuk have been re-engineered to 'swim in the huge pool' formed by the conventional bond (debt) markets which have at least two characteristics. Firstly, the claims on the borrower (pure credit risk - independent of the success of the project or performance and survival of the asset), where possible are secured by additional collateral and ranking preferential over equity. Secondly, steady and fixed income generation exist where pre-agreed returns (based on interest rates) do not depend on any real underlying profit or loss. These structural features practically turned the equity-based profitand-loss sharing arrangements into fixed-income instruments. This kind of innovation is trying to achieve the same economic outcome as conventional instruments, which mean in effect distorting the vision of Islamic economics based on justice and equitability.

Idealizing Shariah prescriptions of equity-based sukuk structure may not be attractive to conventional mind-set risk-averse investors. In particular, the characteristics of mudharabah and musharakah do not meet the risk appetite of investors who mainly expect capital preservation and fixed income instruments as commonly featured in conventional bond instruments (Ghani, 2009). In the market, investors, on their part, do not want to become owners of assets and assume the risks of ownership. They only want their profits to be guaranteed and to earn them rewards without taking a risk (Abdullah, 2012).

Pressure on the "investors' 'appetite' towards fixed return" resulted the vast majority (90\%) of sukuk in the market being structured to mimic conventional unsecured bonds (Hassoune, 2010). These contexts demonstrate that the investing public wants an "Islamic" structure, yet in the meantime the features of a debt are also evident. Therefore following the paradox in structuring equity-based sukuk, some practitioners contend that the real issue for the default of Islamically structured Dubai bonds is mostly based on Shariah advisers appearing to be increasingly driven by rising demands of commerce for them. This is forcing them to show more flexibility when they rule on the validity of large financial transactions (Saleem, 2010). 


\section{Conclusion}

Since conventional bonds constitute a pure debt obligation, this interest-bearing debt has an inherent conflict of interest between the lender and the borrower, which results in the possibility of the corporate issuer defaulting on its debt obligations. In Islamic finance, the idealizations of profit-sharing as prescribed in the Shariah rules do not represent a conflict of interest between the two parties, particularly for the equity-based sukuk. The same conflicts, if or when they do happen, exhibit a flaw in the structuring of the product despite its formulation as a partnership. This downplays the seriousness of the Shariah objectives in the midst of justified worries about the credit crisis. The defaults described here make it clear that the sukuk that defaulted were not designed to share risk, but to confine it to issuers. Had the sukuk been designed to share risk, investors would have had to share losses with issuers. There would have been no defaults, only losses.

Nevertheless, when some innovations in sukuk which try to achieve the same economic outcomes like conventional instruments, they end up distorting the intention of Islamic economics based on justice and equitability. Indeed, an oft-heard criticism of Shariah compliance with reference to finance, is the flexibility of scholars in approving financing plans that are practically indistinguishable from conventional structures. As the industry gains a foothold in the global financial market, it will be interesting to follow whether renewed diligence on the part of Shariah scholars results in a finance market that is more readily distinguishable from the conventional one. It will also be interesting to see what role these questions will play in the fallout if or when the next high profile sukuk default is not averted.

\section{Acknowledgement}

The support from the Fundamental Research Grant Scheme (FRGS) [Grant Number:203.PJJAUH.6711547], Ministry of Education, Malaysia and Universiti Sains Malaysia are

\section{References} gratefully acknowledged.

Abdullah, A. K. (2011). Overcoming the weaknesses in sukuk: toward risk-sharing instruments in Islamic finance. Islam and Civilisational Renewal, 2(4), 669-670.

Abdullah, A. K. (2012). Asset-backed vs asset-based sukuk. Kuala Lumpur: International Institute of Advanced Islamic Studies.

Al-Amine, M. A.-B. M. (2011). Global sukūk and Islamic securitization market: financial engineering and product innovation. Leiden: Brill Academic Pub.

Ali, S. S. (2016). Islamic Șukūk default and issues in their resolution: the case of Villamar Sukūk. Islamic Research and Training Institute, Jeddah: IRTI Working Paper Series WP/2016/05.

Alsayyed, N. A. H. (2011). Equity-based sukuk pricing model: shariah risk assessments of al-wand almulzim in Malaysia and GCC capital markets. (Phd), Phd Dissertation, The Global University Of Islamic Finance Malaysia, Kuala Lumpur.

Ariff, M., Safari, M., \& Mohamad, S. (2012). Sukuk securities, their definitions, classification and pricing issues. In M. Ariff, M. Iqbal, \& S. Mohamad (Eds.), The Islamic Debt Market for Sukuk Securities: The Theory and Practice of Profit Sharing Investment (pp. 11-41). Cheltenham and Massachusetts: Edward Elgar.

El-Hawary, D., Grais, W., \& Iqbal, Z. (2004). Regulating Islamic financial institutions: the nature of the regulated Research Working Paper No. 3227. Washington D.C.: The World Bank.

Friel, S., \& Kumpf, S. N. (2015). Sukuk default. Retrieved from https://www.financierworldwide.com/sukuk-default/\#.WrxTZk0h34Y

Ghani, B. A. (2009). Is AAOIFI ban on musharaka sukuk justified?”. Islamic banker, 160/161, 10-16. 
Hassoune, A. (2010). The meaning of ratings for Islamic Financial Institutions. Islamic Finance News, 7(26), 17-18.

IIFM. (2009). Sukuk report (1 ed.). Manama: International Islamic Financial Market.

Iqbal, Z., \& Mirakhor, A. (2007). An introdution to Islamic finance: theory and practice. Chichester: John Wiley \& Sons Ltd.

IRTI. (2013). Risk management of sukuk Islamic bonds. Retrieved from Jeddah:

Kapetanovic, H., \& Becic, M. (2009). Mudharabah sukuk: essential Islamic contract, applications and the way forward. In A. Thomas (Ed.), Sukuk (pp. 223-247). Petaling Jaya: Sweet \& Maxwell Asia.

Khan, N. (2010). Islamic finance guide. Retrieved from Abu Dhabi:

Khnifer, M. (2011). Shocking: 21 defaulted sukuk cases in the last 20 months! Business Islamica Magazine, 24-26.

Kidwai, F. (2009). Restructuring or reorganising. London: IFR Islamic Finance Report, Thomson Reuters.

Majid, H. A., Shahimi, S., \& Abdullah, M. H. S. B. (2011). Sukuk defaults and its implication: a case study of Malaysian capital market. Qatar, 19-21 December 2011: paper presented at the 8 th International Conference on Islamic Economics and Finance.

Moody's. (2011). EDF Overview: from Moody's analytics. New York: Moody's Investor Services.

Parker, M. (2010). Sukuk defaults turn spotlight on governance process. Retrieved from http://www.arabnews.com/node/352244

Radzi, R. M., \& Muhamed, N. A. (2012). An international comparative study on Shariah governance supervision of sukuk defaults. Journal of Islamic Economics, Banking and Finance, 4(3), 20-43.

Remo-Listana, K. (2010). 'Market, not methodology', drives sukuk defaults. Retrieved from http://www.zawya.com/Story.cfm/sidZAWYA20100615042212

Reuters. (2010). Gulf Holding says no cash crunch at Villamar sukuk. Retrieved from http://www.arabianbusiness.com/gulf-holding-says-no-cash-crunch-at-villamar-sukuk-182286.html

Saeed, A., \& Salah, O. (2012). Development of sukuk: pragmatic and idealist approaches to sukuk structures. In M. Ariff, M. Iqbal, \& S. Mohamad (Eds.), The Islamic Debt Market for Sukuk Securities: The Theory and Practice of Profit Sharing Investment (pp. 42-66). Cheltenham: Edward Elgar Publishing.

Salah, O. (2011). Islamic finance: the impact of the AAOIFI resolution on equity-based sukuk structures. TISCO Working Paper Series on Banking, Finance and Services(2).

Saleem, M. A. (2010). Sukuk default: questions about Shari'ah supervision. Retrieved from http://www.newhorizon-islamicbanking.com/index.cfm?action=view\&id=10925\&section=features

Syed Ali, S. (2017). Șukūk Default and Issues in Their Resolution: The Case of Villamar Șukūk. In I. S. Syed Aun R. Rizvi (Ed.), Developments in Islamic Finance: challenges and initiatives (pp. 65-88). Gewerbestrasse, Switzerland: Springer International Publishing AG.

Trad, S. A., \& Bhuyan, R. (2015). Prospect of sukuk in the fixed income market: a case study on Kuwait financial market. International Journal of Financial Research, 6(4), 175-186.

Trade Arabia. (2010). Gulf Holding rejects cash crunch fears. Retrieved from http://www.tradearabia.com/news/BANK 179003.html

Usmani, M. T. (1999a). The concept of musharakah and its application as an islamic method of financing. Arab Law Quarterly, 14(3), 203-220

Usmani, M. T. (1999b). An introduction to Islamic finance. Karachi: Maktaba Mariful.

Usmani, M. T. (2002). An Introduction to Islamic Finance. The Hague: Kluwer Law International.

Usmani, M. T. (2007). Sukuk and their contemporary applications. Retrieved from http://www.failaka.com/downloads/Usmani_SukukApplications.pdf

Yean, T. W. (2009). Sukuk: issues and the way forward. International Legal News, 6(2). Retrieved from http://www.imakenews.com/iln/e_article001562699.cfm?x=b11,0,w

Zaheer, S., \& Wijnbergen, S. J. G. v. (2013). Sukuk defaults: on distress resolution in Islamic Finance. Tinbergen Institute Amsterdam: Tinbergen Institute Discussion Paper. 